\title{
OCCURRENCE OF TWO-SPOTTED SPIDER MITE (TETRANYCHUS URTICAE KOCH) ON POTENTILLA FRUTICOSA CULTIVARS
}

\section{Short communication}

\author{
Piotr SZAFRANEK* \\ Research Institute of Horticulture \\ Konstytucji 3 Maja 1/3, 96-100 Skierniewice, Poland \\ Received May 2016; Accepted: November 2016
}

\begin{abstract}
Potentilla fruticosa L. (Rosaceae Juss.) is one of the most popular deciduous shrubs cultivated in Poland. Among pests identified so far on P. fruticosa, a serious threat is caused by two-spotted spider mite Tetranychus urticae Koch (Acari: Tetranychidae). During three-year study, the occurrence of two-spotted spider mite T. urticae on four cultivars of P. fruticosa: 'Goldfinger', 'McKay's White', 'Uman' and 'Pink Beauty' grown in field conditions was compared. While conducting experiment, weather conditions were monitored. The number of eggs and motile forms of two-spotted spider mite were recorded separately. The most attractive cultivar to spider mite was 'Goldfinger'. The largest amount of motile forms of mites and their eggs were found on the leaves of this cultivar in all three years of study. The least number of pests occurred on the cv. 'Pink Beauty'. However, differences in the abundance of this pest on all studied cultivars were variable during the growing seasons.
\end{abstract}

Key words: spider mite, population dynamics, shrubby cinquefoil, comparison

\section{INTRODUCTION}

Shrubby cinquefoil Potentilla fruticosa is commonly found in the Northern Hemisphere in America and Asia as well as in some parts of Europe (Seneta \& Dolatowski 2000). It is also one of the most popular deciduous shrubs cultivated in Poland (Marosz 2011). In nursery crops, there are numerous garden cultivars of this species differing in height, shape and flower and foliage colour (Seneta \& Dolatowski 2000; Czekalski 2005). Despite the widespread and popularity of $P$. fruticosa, there is little information about pests occurring on these plants.

Two-spotted spider mite Tetranychus urticae Koch (Acari: Tetranychidae) is a serious pest of many agricultural and horticultural crops, including ornamentals (Jeppson et al. 1975; Helle \& Sabelis 1985). Harmful are all motile forms of this species: larvae, nymphs and adults. With a large number of pests, the leaves infested by mites deform and whole plants wither, grow lesser and produce lower yields; however, it should be noted that especially in case of ornamental plants, even small number of pests can cause a loss their value.

Development of mites in field conditions depends on many different factors. The most obvious are temperature, humidity, rain, phototaxis and host plants (Jeppson et al. 1975). It is known that plants have a wide range of toleration to mite pests (Jeppson et al. 1975). The differences in mite infestation or development on plants are observed among many plant species and cultivars (Labanowska 1992, 2007; Witul \& Kiełkiewicz 1999; Skorupska 2004; Kazak \& Kibritçi 2008; Landeros Flores et al. 2013). Resistance and susceptibility to pests are very important characteristics in integrated pest management (Flint \& Bosch 1981; Ehi-Eromosele et al. 2013), which is mandatory in many countries. 
The aim of this study was to compare attractiveness of different cultivars of $P$. fruticosa to spider mite T. urticae.

\section{MATERIALS AND METHODS}

The experiment was conducted during 2012 to 2014, in the experimental fields of the Research Institute of Horticulture in Skierniewice. The experiment was conducted in a randomised block design with three replications, on plots of the area of $10 \mathrm{~m}^{2}$. Observations of spider mite populations inhabiting Potentilla plants were carried out since formation till when the leaves dry out and fall off. While conducting experiments, weather conditions were monitored (Table 1). The data came from meteorological stations located in Skierniewice. The study was conducted on four cultivars of P. fruticosa: 'Goldfinger', 'McKay's White', 'Uman' and 'Pink Beauty' described in Table 2. To determine the number of hairs on the abaxial leaf surface 20 , the same age leaves from each cultivar were collected. The number of hairs per $1 \mathrm{~cm}^{2}$ was calculated based on a number of hairs on the area of $4 \mathrm{~mm}^{2}$.

To assess plant attractiveness to spider mite from each cultivar in each replication, five plants were selected for sampling. From each plant, four leaves were taken every 14-20 days. For the analysis, only pinnate leaves consisting of five leaves were collected. Leaves were taken randomly from the middle parts of plants. Each leaf was packed separately into a plastic bag. The leaves immediately after collecting were transported to the laboratory and reviewed under the stereoscopic microscope. The number of eggs and motile forms of two-spotted spider mite were recorded separately. Because of the large pest abundance on cv. 'Goldfinger', on 4 and 18 June 2012, in order to protect plants against damage, acaricide containing Fenpyroximate (Ortus 05 SC) was used on all plants in the experiment at a concentration $0.1 \%$.

Table 1. Weather conditions in Skierniewice during conducting of experiment in 2012-2014

\begin{tabular}{lccccccccc}
\hline \multirow{2}{*}{ Month } & \multicolumn{3}{c}{$\begin{array}{c}\text { Mean monthly air temperature } \\
\left({ }^{\circ} \mathrm{C}\right)\end{array}$} & \multicolumn{3}{c}{$\begin{array}{c}\text { Mean monthly relative } \\
\text { humidity }(\%)\end{array}$} & \multicolumn{3}{c}{$\begin{array}{c}\text { Sum of monthly precipitation } \\
(\mathrm{mm})\end{array}$} \\
\cline { 2 - 10 } & 2012 & 2013 & 2014 & 2012 & 2013 & 2014 & 2012 & 2013 & 2014 \\
\hline April & 15.1 & 8.0 & 9.6 & 58.2 & 76.5 & 79.3 & 50.0 & 10.6 & 52.6 \\
May & 15.3 & 15.2 & 13.9 & 65.6 & 78.4 & 75.6 & 17.6 & 80.0 & 95.2 \\
June & 17.1 & 18.5 & 16.3 & 72.7 & 77.3 & 72.5 & 62.0 & 129.2 & 26.4 \\
July & 20.6 & 20.2 & 21.1 & 70.0 & 66.4 & 72.6 & 72.0 & 12.4 & 67.6 \\
August & 18.9 & 19.5 & 18.1 & 72.3 & 66.2 & 76.6 & 60.6 & 32.8 & 69.4 \\
September & 14.4 & 12.2 & 15.0 & 76.4 & 82.6 & 81.2 & 36.6 & 60.0 & 29.4 \\
October & 11.0 & 10.1 & 11.4 & 74.1 & 85.0 & 87.8 & 34.2 & 3.0 & 15.8 \\
\hline
\end{tabular}

Table 2. Characteristics of the studied cultivars

\begin{tabular}{lcccc}
\hline \multirow{2}{*}{ Parameter } & \multicolumn{4}{c}{ Cultivar } \\
\cline { 2 - 5 } & 'Goldfinger' & 'McKay's White' & 'Uman' & 'Pink Beauty' \\
\hline Maximum height $(\mathrm{cm})$ & 100 & 120 & 60 & 50 \\
Maximum width $(\mathrm{cm})$ & 100 & 150 & 60 & 80 \\
Shape & dense & branchy & dense & branchy \\
Flowering period & VI-X & VI-IX & V-X & VI-X \\
Flower color & yellow & white & yellow-red & pink \\
Number of hairs per $1 \mathrm{~cm}^{2}$ on & 1953.8 & 255.5 & 289.3 & 724.2 \\
abaxial surface of leaves & & & & \\
\hline
\end{tabular}


For the analyses, the statistical program 'Statistica 10 PL' was applied. Data on population dynamics were analysed by Kruskal-Wallis analysis of variance (ANOVA) on Ranks and Dunn's test for multiple comparisons at $\mathrm{p}=0.05$. Data on Potentilla spp. cultivars susceptibility to the two-spotted spider mite were transformed using the function $y=\log (x+1)$. Cumulative index of infestation

$$
(\mathrm{CII})=\sum_{n=1}^{n=k-1}\left(\frac{t_{n}}{2} \cdot\left(x_{n}+x_{n+1}\right)\right)
$$

where: $k$ is the number of occasions on which the mites were counted; $x_{n}, x_{n+1}$ are consecutive indices; $t_{n}$ is the time, in days, between the consecutive indices) was then calculated by Wratten et al. (1979) and analysed by one-way analysis of variance followed by Dunnett's test for comparison against a reference cv. 'Goldfinger' at $\mathrm{p}=0.05$. Relative CIIs for each cultivar were then calculated.

\section{RESULTS AND DISCUSSION}

The results presented in Table 3 show that the most attractive to spider mite was cv. 'Goldfinger'. The largest amount of motile forms and eggs were found on the leaves of this variety in all three years of study. This cultivar is characterised by large size, compact structure and the higher number of hairs on abaxial surface of leaves as compared to other studied cultivars. The least number of pests occurred on the cv. 'Pink Beauty', which is characterised by small size, a branchy structure and a moderate number of hairs on abaxial surface of leaves (Table 2). The number of motile forms of mites in this cultivar in each year of the study was about two or three times lower than in the cv. 'Goldfinger'. In the literature, there are reports on the influence of plant morphology and anatomy on spider-mite population development (Boczek 1999). However, the correlation between them and population density of $T$. urticae can be controversial (Skorupska 2004).

So far, spider mites on $P$. fruticosa were observed by Pratt et al. (2002), Soika \& Łabanowski (2003 \& 2015), but the authors did not compare the susceptibility of cultivars to the spider mite with the exception of Soika \& Łabanowski (2015) paper, who reported that in Polish nurseries the most often inhabited was cv. 'Red Ace', which has hairy leaves on both sides.

The experiment shows that an attractiveness of $P$. fruticosa to spider mite was variable during the growing season (Tables 4-6). In some periods of the seasons, especially when number of mites was low, there were no differences between cultivars. Differences of spider mite population during season in field conditions was also reported by a few authors. Roy et al. (1999) observed seasonal fluctuations of two Tetranychus species (T. mcdanieli McGregor and T. urticae) occurring on raspberry in different field conditions. Mite population changes during season was as well described by Keetch (1971) who studied ecology of citrus red mite Panonychus citri (McGregor) in an orange orchard. Changes in seasonal abundance of mites may be due to the fact that the development of mites depends also on temperature and humidity (Jeppson et al. 1975). These factors are variable during the season and it causes changes in the dynamics of populations of mites.

Two spotted spider mite is one of the most important crop pests and also the most resistant species causing many problems worldwide (Van Leeuwen et al. 2010). One of the methods for the control of this pests is the use of resistant cultivars. It is advisable to conduct future studies on the nature of resistance/susceptibility of P. fruticosa cultivars, including their nutritional values to twospotted spider mite.

Table 3. The cumulative index of infestation of motile forms and eggs of mites in different years in comparison to 'Goldfinger' as a reference (100\%)

\begin{tabular}{lrrrrrr}
\hline \multirow{2}{*}{ Cultivar } & \multicolumn{2}{c}{2012} & \multicolumn{2}{c}{2013} & \multicolumn{2}{c}{2014} \\
\cline { 2 - 7 } & Motile & Eggs & Motile & Eggs & Motile & Eggs \\
\hline 'Pink Beauty' & $36.5 \mathrm{a}$ & $34.3 \mathrm{a}$ & $50.5 \mathrm{a}$ & $65.6 \mathrm{a}$ & $38.1 \mathrm{a}$ & $39.7 \mathrm{a}$ \\
'Uman' & $59.9 \mathrm{a}$ & $64.6 \mathrm{a}$ & $57.2 \mathrm{a}$ & $67.4 \mathrm{a}$ & $43.6 \mathrm{a}$ & $60.6 \mathrm{~b}$ \\
'McKay's White' & $60.4 \mathrm{a}$ & $62.5 \mathrm{a}$ & $73.9 \mathrm{a}$ & $69.0 \mathrm{a}$ & $61.6 \mathrm{a}$ & $47.4 \mathrm{a}$ \\
'Goldfinger' & $100.0 \mathrm{~b}$ & $100.0 \mathrm{~b}$ & $100.0 \mathrm{~b}$ & $100.0 \mathrm{~b}$ & $100.0 \mathrm{~b}$ & $100.0 \mathrm{~b}$ \\
\hline
\end{tabular}

Means in columns followed by the same letter are not significantly different using Dunnett's test for comparison against 'Goldfinger' $c v$. at $\mathrm{p}=0.05$. 
Table 4. Seasonal fluctuations of motile forms and eggs of two-spotted spider mite in 2012

\begin{tabular}{ccccccccc}
\hline & \multicolumn{9}{c}{ Motile } & \multicolumn{3}{c}{ Eggs } \\
\cline { 2 - 8 } Date & 'Goldfinger' & $\begin{array}{c}\text { 'McKay's } \\
\text { White' }\end{array}$ & 'Uman' & $\begin{array}{c}\text { 'Pink } \\
\text { Beauty' }\end{array}$ & 'Goldfinger' & $\begin{array}{c}\text { 'McKay's } \\
\text { White' }\end{array}$ & 'Uman' & $\begin{array}{c}\text { 'Pink } \\
\text { Beauty' }\end{array}$ \\
\hline $31-05$ & $6.02 \mathrm{a}$ & $1.15 \mathrm{~b}$ & $1.30 \mathrm{~b}$ & $0.50 \mathrm{~b}$ & $17.05 \mathrm{a}$ & $5.50 \mathrm{~b}$ & $3.47 \mathrm{bc}$ & $1.08 \mathrm{c}$ \\
$15-06$ & $3.62 \mathrm{a}$ & $0.23 \mathrm{~b}$ & $0.37 \mathrm{~b}$ & $0.10 \mathrm{~b}$ & $5.97 \mathrm{a}$ & $0.62 \mathrm{~b}$ & $0.98 \mathrm{~b}$ & $0.18 \mathrm{~b}$ \\
$29-06$ & $1.27 \mathrm{a}$ & $0.30 \mathrm{ab}$ & $0.12 \mathrm{~b}$ & $0.15 \mathrm{~b}$ & $5.12 \mathrm{a}$ & $2.40 \mathrm{~b}$ & $0.40 \mathrm{~b}$ & $0.75 \mathrm{~b}$ \\
$12-07$ & $0.27 \mathrm{a}$ & $0.22 \mathrm{a}$ & $0.37 \mathrm{a}$ & $0.05 \mathrm{a}$ & $0.17 \mathrm{a}$ & $0.57 \mathrm{a}$ & $0.93 \mathrm{a}$ & $0.17 \mathrm{a}$ \\
$25-07$ & $0.12 \mathrm{a}$ & $0.37 \mathrm{a}$ & $0.60 \mathrm{a}$ & $0.08 \mathrm{a}$ & $0.08 \mathrm{a}$ & $0.68 \mathrm{a}$ & $2.18 \mathrm{a}$ & $0.25 \mathrm{a}$ \\
$09-08$ & $0.10 \mathrm{a}$ & $0.45 \mathrm{a}$ & $0.50 \mathrm{a}$ & $0.22 \mathrm{a}$ & $0.23 \mathrm{a}$ & $0.87 \mathrm{a}$ & $1.82 \mathrm{a}$ & $0.58 \mathrm{a}$ \\
$23-08$ & $0.30 \mathrm{a}$ & $0.48 \mathrm{a}$ & $0.73 \mathrm{a}$ & $0.07 \mathrm{a}$ & $0.90 \mathrm{ab}$ & $0.93 \mathrm{ab}$ & $1.70 \mathrm{a}$ & $0.10 \mathrm{~b}$ \\
$06-09$ & $0.72 \mathrm{a}$ & $0.50 \mathrm{ab}$ & $0.60 \mathrm{ab}$ & $0.15 \mathrm{~b}$ & $1.07 \mathrm{ab}$ & $1.08 \mathrm{a}$ & $0.65 \mathrm{ab}$ & $0.28 \mathrm{~b}$ \\
$20-09$ & $0.50 \mathrm{a}$ & $0.27 \mathrm{a}$ & $0.15 \mathrm{a}$ & $0.08 \mathrm{a}$ & $0.97 \mathrm{a}$ & $0.22 \mathrm{a}$ & $0.38 \mathrm{a}$ & $0.25 \mathrm{a}$ \\
$04-10$ & $0.57 \mathrm{a}$ & $0.52 \mathrm{a}$ & $0.30 \mathrm{a}$ & $0.33 \mathrm{a}$ & $0.27 \mathrm{a}$ & $0.22 \mathrm{a}$ & $0.22 \mathrm{a}$ & $0.05 \mathrm{a}$ \\
$18-10$ & $0.38 \mathrm{a}$ & $0.28 \mathrm{a}$ & $0.17 \mathrm{a}$ & $0.17 \mathrm{a}$ & $0.00 \mathrm{a}$ & $0.00 \mathrm{a}$ & $0.07 \mathrm{a}$ & $0.00 \mathrm{a}$ \\
\hline
\end{tabular}

Means in a line for motile forms and eggs separately followed by different letters are significantly different using Dunn test at $\mathrm{p}=0.05$.

Table 5. Seasonal fluctuations of motile forms and eggs of two-spotted spider mite in 2013

\begin{tabular}{ccccccccc}
\hline & \multicolumn{9}{c}{ Motile } & \multicolumn{3}{c}{ Eggs } \\
\cline { 2 - 8 } Date & 'Goldfinger' & $\begin{array}{c}\text { 'McKay's } \\
\text { White' }\end{array}$ & 'Uman' & $\begin{array}{c}\text { 'Pink } \\
\text { Beauty' }\end{array}$ & 'Goldfinger' 'McKay's \\
White' & 'Uman' & $\begin{array}{c}\text { 'Pink } \\
\text { Beauty' }\end{array}$ \\
\hline $15-05$ & $0.08 \mathrm{a}$ & $0.03 \mathrm{a}$ & $0.05 \mathrm{a}$ & $0.00 \mathrm{a}$ & $0.10 \mathrm{a}$ & $0.00 \mathrm{a}$ & $0.07 \mathrm{a}$ & $0.13 \mathrm{a}$ \\
$12-06$ & $0.35 \mathrm{a}$ & $0.13 \mathrm{ab}$ & $0.07 \mathrm{ab}$ & $0.00 \mathrm{~b}$ & $2.77 \mathrm{a}$ & $0.58 \mathrm{ab}$ & $0.72 \mathrm{ab}$ & $0.28 \mathrm{~b}$ \\
$26-06$ & $2.12 \mathrm{a}$ & $0.95 \mathrm{bc}$ & $0.82 \mathrm{ab}$ & $0.08 \mathrm{c}$ & $4.72 \mathrm{a}$ & $2.10 \mathrm{ab}$ & $2.78 \mathrm{a}$ & $0.32 \mathrm{~b}$ \\
$09-07$ & $1.78 \mathrm{a}$ & $1.10 \mathrm{ab}$ & $0.52 \mathrm{~b}$ & $0.32 \mathrm{~b}$ & $4.45 \mathrm{a}$ & $3.20 \mathrm{ab}$ & $1.93 \mathrm{~b}$ & $1.68 \mathrm{~b}$ \\
$25-07$ & $0.58 \mathrm{a}$ & $0.68 \mathrm{a}$ & $0.22 \mathrm{a}$ & $0.55 \mathrm{a}$ & $1.30 \mathrm{a}$ & $0.88 \mathrm{a}$ & $0.68 \mathrm{a}$ & $2.42 \mathrm{a}$ \\
$07-08$ & $0.43 \mathrm{ab}$ & $0.93 \mathrm{a}$ & $0.27 \mathrm{~b}$ & $0.72 \mathrm{ab}$ & $0.62 \mathrm{a}$ & $1.22 \mathrm{a}$ & $1.18 \mathrm{a}$ & $2.00 \mathrm{a}$ \\
$28-08$ & $0.65 \mathrm{a}$ & $0.20 \mathrm{a}$ & $0.40 \mathrm{a}$ & $0.37 \mathrm{a}$ & $1.15 \mathrm{a}$ & $0.07 \mathrm{a}$ & $0.53 \mathrm{a}$ & $0.75 \mathrm{a}$ \\
$04-09$ & $0.75 \mathrm{a}$ & $0.25 \mathrm{a}$ & $0.15 \mathrm{a}$ & $0.13 \mathrm{a}$ & $1.18 \mathrm{a}$ & $0.48 \mathrm{~b}$ & $0.40 \mathrm{~b}$ & $0.32 \mathrm{ab}$ \\
$27-09$ & $1.00 \mathrm{a}$ & $0.27 \mathrm{ab}$ & $0.17 \mathrm{~b}$ & $0.17 \mathrm{~b}$ & $0.80 \mathrm{a}$ & $0.03 \mathrm{a}$ & $0.23 \mathrm{a}$ & $0.18 \mathrm{a}$ \\
$09-10$ & $0.47 \mathrm{a}$ & $0.08 \mathrm{a}$ & $0.20 \mathrm{a}$ & $0.07 \mathrm{a}$ & $0.27 \mathrm{a}$ & $0.02 \mathrm{a}$ & $0.27 \mathrm{a}$ & $0.00 \mathrm{a}$ \\
$23-10$ & $0.95 \mathrm{a}$ & $0.03 \mathrm{~b}$ & $0.13 \mathrm{~b}$ & $0.08 \mathrm{~b}$ & $0.03 \mathrm{a}$ & $0.00 \mathrm{a}$ & $0.02 \mathrm{a}$ & $0.00 \mathrm{a}$ \\
\hline
\end{tabular}

Note: See Table 4

Table 6. Seasonal fluctuations of motile forms and eggs of two-spotted spider mite in 2014

\begin{tabular}{ccccccccc}
\hline & \multicolumn{9}{c}{ Motile } & \multicolumn{3}{c}{ Eggs } \\
\cline { 2 - 9 } Date & 'Goldfinger' 'McKay's & $\begin{array}{c}\text { 'Uman' } \\
\text { White' }\end{array}$ & $\begin{array}{c}\text { 'Pink } \\
\text { Beauty' }\end{array}$ & 'Goldfinger', 'McKay's & 'Uman' & $\begin{array}{c}\text { 'Pink } \\
\text { Beauty' }\end{array}$ \\
\hline $22-05$ & $0.00 \mathrm{a}$ & $0.00 \mathrm{a}$ & $0.00 \mathrm{a}$ & $0.00 \mathrm{a}$ & $0.00 \mathrm{a}$ & $0.00 \mathrm{a}$ & $0.00 \mathrm{a}$ & $0.00 \mathrm{a}$ \\
$05-06$ & $0.00 \mathrm{a}$ & $0.02 \mathrm{a}$ & $0.03 \mathrm{a}$ & $0.02 \mathrm{a}$ & $0.10 \mathrm{a}$ & $0.00 \mathrm{a}$ & $0.00 \mathrm{a}$ & $0.00 \mathrm{a}$ \\
$25-06$ & $0.07 \mathrm{a}$ & $0.03 \mathrm{a}$ & $0.05 \mathrm{a}$ & $0.02 \mathrm{a}$ & $1.37 \mathrm{a}$ & $0.75 \mathrm{a}$ & $0.60 \mathrm{a}$ & $0.20 \mathrm{a}$ \\
$04-07$ & $0.50 \mathrm{a}$ & $0.42 \mathrm{a}$ & $0.23 \mathrm{a}$ & $0.02 \mathrm{a}$ & $1.25 \mathrm{a}$ & $0.57 \mathrm{a}$ & $1.55 \mathrm{a}$ & $0.28 \mathrm{a}$ \\
$21-07$ & $1.45 \mathrm{a}$ & $0.55 \mathrm{ab}$ & $0.40 \mathrm{ab}$ & $0.25 \mathrm{~b}$ & $2.02 \mathrm{a}$ & $0.68 \mathrm{a}$ & $1.03 \mathrm{a}$ & $1.05 \mathrm{a}$ \\
$30-07$ & $0.45 \mathrm{a}$ & $0.68 \mathrm{a}$ & $0.20 \mathrm{a}$ & $0.17 \mathrm{a}$ & $1.65 \mathrm{a}$ & $0.38 \mathrm{a}$ & $0.72 \mathrm{a}$ & $0.23 \mathrm{a}$ \\
$14-08$ & $0.28 \mathrm{a}$ & $0.07 \mathrm{ab}$ & $0.00 \mathrm{~b}$ & $0.03 \mathrm{ab}$ & $0.72 \mathrm{a}$ & $0.12 \mathrm{a}$ & $0.12 \mathrm{a}$ & $0.02 \mathrm{a}$ \\
$28-08$ & $0.23 \mathrm{a}$ & $0.02 \mathrm{a}$ & $0.00 \mathrm{a}$ & $0.10 \mathrm{a}$ & $1.00 \mathrm{a}$ & $0.18 \mathrm{a}$ & $0.00 \mathrm{a}$ & $0.07 \mathrm{a}$ \\
$11-09$ & $0.82 \mathrm{a}$ & $0.03 \mathrm{~b}$ & $0.00 \mathrm{~b}$ & $0.05 \mathrm{~b}$ & $1.67 \mathrm{a}$ & $0.08 \mathrm{a}$ & $0.15 \mathrm{a}$ & $0.13 \mathrm{a}$ \\
$25-09$ & $0.47 \mathrm{a}$ & $0.12 \mathrm{a}$ & $0.07 \mathrm{a}$ & $0.05 \mathrm{a}$ & $0.35 \mathrm{a}$ & $0.00 \mathrm{a}$ & $0.37 \mathrm{a}$ & $0.02 \mathrm{a}$ \\
$16-10$ & $0.20 \mathrm{a}$ & $0.03 \mathrm{a}$ & $0.13 \mathrm{a}$ & $0.03 \mathrm{a}$ & $0.00 \mathrm{a}$ & $0.00 \mathrm{a}$ & $0.05 \mathrm{a}$ & $0.05 \mathrm{a}$ \\
\hline
\end{tabular}

Note: See Table 4 


\section{CONCLUSIONS}

1. The investigated cultivars of $P$. fruticosa differed in attractiveness to spider mite $T$. urticae.

2. Differences in the level of infestation of all studied cultivars were variable during the growing seasons.

3. Among the investigated cultivars 'Goldfinger' turned out to be the most attractive while 'Pink Beauty' the most resistant to spider mite.

\section{Acknowledgements}

The author thanks researchers from Research Institute of Horticulture: Dr. Adam Marosz and MSc Grzegorz Falkowski for help in designing and conducting the experiment, MSc Katarzyna Woszczyk for help in the collection of plant materials and MSc Andrzej Lewandowski for help in statistical data analysis.

\section{REFERENCES}

Boczek J. 1999. Zarys akarologii rolniczej. Państwowe Wydawnictwo Naukowe, Warszawa, 388 p. [in Polish]

Czekalski M. 2005. Liściaste krzewy ozdobne o wszechstronnym zastosowaniu. Państwowe Wydawnictwo Rolnicze i Leśne, Poznań, 223 p. [in Polish]

Ehi-Eromosele C.O., Nwinyi O.C., Ajani O.O. 2013. Integrated pest management. In: Soloneski S. \& Larramendy M. (Ed.).Weed and pest control - conventional and new challenges. InTech, pp.: 105-116. DOI: $10.5772 / 54476$.

Flint M.L., van den Bosch R. 1981. Introduction to integrated pest management. Plenum Press, New York, 260 p. DOI: 10.1007/978-1-4615-9212-9.

Helle W., Sabelis M.W. 1985. Spider mites: Their biology, natural enemies and control. Vol. 1A. Elsevier, $405 \mathrm{p}$.

Jeppson L.R., Keifer H.H., Baker E.W. 1975. Mites injurious to economic plants. University of California Press, $614 \mathrm{p}$.

Kazak C., Kibritçi C. 2008. Population parameters of Tetranychus cinnabarinus Boisduval (Prostigmata: Tetranychidae) on eight strawberry cultivars. Turkish Journal of Agriculture and Forestry 32(1): 19-27.

Keetch D.P. 1971. Ecology of the citrus red mite. Panonychus citri (McGregor), (Acarina: Tetranychidae) in South Africa. I. The seasonal abundance of $P$. citri in an orchard under natural control. Journal of the Entomological Society of
Southern Africa 34(1): 63-72. http://hdl.handle.net/10520/AJA00128789_2435

Landeros Flores J., Cerna Chávez E., Aguirre-Uribe L.A., Flores Canales R., Ochoa-Fuentes Y.M. 2013. Demographic parameters of Tetranychus urticae (Acari: Tetranychidae) on four Rosa sp. cultivars. Florida Entomologist 96(4): 1508-1512. DOI: 10.1653/024.096.0432.

Łabanowska B.H. 1992. Black currant cultivar infestation with the two-spotted spider mite (Tetranychus urticae Koch). Fruit Science Reports 19(1): 39-46.

Łabanowska B.H. 2007. Susceptibility of strawberry cultivars to the two-spotted spider mite (Tetranychus urticae Koch). Journal of Fruit and Ornamental Plant Research 15: 133-146.

Marosz A. 2011. Pięciornik krzewiasty (cz. I). Szkółkarstwo 6: 7-14. [in Polish]

Pratt P.D., Rosetta R., Croft B.A. 2002. Plant-related factors influence the effectiveness of Neoseiulus fallacis (Acari: Phytoseiidae), a biological control agent of spider mites on landscape ornamental plants. Journal of Economic Entomology 95(6): 1135-1141. DOI: 10.1603/0022-0493-95.6.1135.

Roy M., Brodeur J., Cloutier C. 1999. Seasonal abundance of spider mites and their predators on red raspberry in Quebec, Canada. Environmental Entomology 28(4): 735-747. DOI: 10.1093/ee/28.4.735. Seneta W., Dolatowski J. 2000. Dendrologia. Wydawnictwo Naukowe PWN, Warszawa, 592 p. [in Polish]

Skorupska A. 2004. Resistance of apple cultivars to twospotted spider mite, Tetranychus urticae Koch (Acarina, Tetranychidae) Part II. Influence of leaf pubescence of selected apple cultivars on fecundity of two-spotted spider mite. Journal of Plant Protection Research 44(1): 69-74.

Soika G., Łabanowski G. 2003. Spider mites (Tetranychidae) recorded on ornamental trees and shrubs in nurseries. Journal of Plant Protection Research 43(2): 105-112.

Soika G., Łabanowski G. 2015. Szkodniki ozdobnych krzewów liściastych i pnączy. Plantpress, Kraków, 192 p. [in Polish]

Van Leeuwen T., Vontas J., Tsagkarakou A., Dermauw W., Tirry L. 2010. Acaricide resistance mechanisms in the two-spotted spider mite Tetranychus urticae and other important acari: A review. Insect Biochemistry and Molecular Biology 40(8): 563572. DOI: $10.1016 /$ j.ibmb.2010.05.008.

Witul A., Kiełkiewicz M. 1999. Life-history parameters of two closely related forms of the Tetranychus urticae-complex on different host plants. In: Bruin J., 
van der Geest L.P.S., Sabelis M.W. (Ed.). Ecology and Evolution of the Acari. Kluwer Academic Publishers, pp. 399-404. DOI: 10.1007/978-94-0171343-6_30.

Wratten S.D., Lee G., Stevens D.J. 1979. Duration of several aphid populations and the effects on wheat yield and quality. Proceedings of the 1979 British Crop Protection Conference - Pests and Diseases (10th British Insecticide and Fungicide Conference). Brighton, England. 1: 1-8. 